\title{
The Human Vocation: An Autobiography of Higher Education
}

\author{
by J. McMurtry
}

To be honest, I backed into the academic profession after trying almost everything else. Until then, I perceived the academic's work as a disconnection in symbolic spheres, "merely academic". Only as I came to recognise that concepts are the governors of action did I realize that the real action was thinking through the lifeblind programs I saw all around me. Since thinking through is the vocation of the university, that is where I ended up. But I am getting ahead of myself.

I had to experience the university first. From the day I was an 18-year-old on campus, it was the freest place I had ever been - freedom from the external routines of job and school, freedom from the authority structure that deadened my life-pulse, and freedom to be really good with the best. Eventually I got the idea of the searching mind as a common horizon that stretched from behind and opened over the millennia, and I never got over the exhilaration. It was like being timeless and unbound.

But it took me a while to get there. I began as a typical active boy. I did not like being in a classroom when I could be moving and self-directed, and I did not like exams. I just knew through high school that I had to do everything required "to get a university education". This was a given in my family, but I had no idea of any career. The idea always seemed to me a closure. That was the beauty of the university. You did not have to choose a career. Who knew what you would want to do then when it was now, and you were still learning what really interested you. Intelligence is interest, I figured out early on.

A job? For me, it could be working in the prisons with the most oppressed people in our society, those who are caged, or it could be, at the other end, the applied psychology of advertising which fascinated me by tapping into people's desires. Or it could be a lawyer like my father and two older brothers - my context was full of the legal profession. But I hated the idea of having to call judges "my lord" or being ingratiating to the rich. Perhaps I could be a writer since I'd published erratically since I was 12. But once in university, the questions faded. I was so busy giving myself full speed to what the academy had to offer that I had no time for the pre-laid road of a "career". I blessed the university as a place where freedom from a career was possible - approximately the opposite conception of today when it is reduced to an instrument of "the job market".

Opening the Gates of the Soul:

Confessions of a Non-Careerist 
The university was beautiful because it advocated critical autonomy of understanding, and demanded all you had to perfect what you were doing with mind or body. I skipped classes a lot, but the courses were captivating when I finally buckled down to learn a year's work in the last month. Grades at the University of Toronto where I went in 1957 were determined by three-hour final exams, and as a result of my method I still experience nightmares of the exam I haven't managed to study for. But I loved the deep contract of freedom for high performance. That was the silent covenant of the University as I experienced it, and it was worth anything to keep. No price was too much in the way of broken bones and joints on the playing fields and exam terrors in the springtime.

Studies were what you had to do to keep your end of the contract. The least work input possible for the most grade return was the secret code. The ethos of the market ruled. But I got more and more seduced by high-octane exam studies into a connective thinking from which, eventually, I could never come back. It did not occur to me that I would one day become an academic even as I was becoming one. I only continued past my undergraduate degree in the first place because my mother was adamant about " not wasting your brain on football". I had been offered a contract and bonus to sign by the Calgary Stampeders which was too much to resist. Being wooed by a team whose romantic symbol of a cowboy on a bucking horse had been with me since Calgary won the 1949 Grey Cup when I was ten, I felt a vast gladness of arrival to do what I'd wanted to do since I could run with a ball. I played football in Calgary as a cornerback in the Fall of that year as the only starting player in the CFL from Canada's universities. But when we almost went to the Grey Cup as what was called "the Cinderella team", my mother was busy reeling me back in. She managed to get the university to accept me into grad school while I was out of province playing football, and my grades were enough to manage it.

My mother did not know what a good idea that was. She didn't wonder about the games of violence as the commercial world's main advertising site, mostly for addictive commodities. Nor did she feel what it was like being a broken on a wheel to provide entertainment for masses. That was what I figured out when I went back to becoming more learned with the learned. It turned out to be early December before I returned from the Western League Football Finals, making 22 tackles with a body harness around my dislocated shoulder. The academy's open door then changed my life. I rushed back to immerse for the first time in every class.

The sequence of pro athlete becoming philosophy graduate student halfway through the year probably could not happen today. Graduate departments are presided over by administrators and rules that exclude it automatically. In practice, live professors know better. It was obvious to me in the first graduate seminar I got to that the open informed inquiry of the scholar was heaven next to the dramatic violence of being inside the coliseum. I was very glad to have been on the Cinderella team until the clock struck midnight, but I had had my fill. At the same time, however, I was reasonably convinced that the mannered abstractions of the academy could not meet the challenges of the real world. Its normalized stupefaction and oppression were apparent to me, and the academy seemed to have its head where the sun could not 
shine - flying around in ever tighter circles until it disappeared into self-referential knots.

Something had to be done in the trenches, I thought. My motivation had somehow changed from getting on top in power and prestige to the opposite - to fighting up from the bottom to teach the least how to think, read and write. I wanted to share the freedom to inquire and the worlds of reason, poetry and letters I had been liberated by at the university with those who would otherwise not know their wonders. I wanted to disseminate the academy's vocation at the level of the street. To make a long story short, I was financially supported by the Toronto Board of Education in getting a Type A English Teacher Certificate to go into the toughest inner-city schools as a specialist teacher. I was part of a wider movement of "blackboard jungle" teachers in inner-city schools. It was like having a 200-kid family. Their literacy development and joy in self expression kept me going most of the 70-hours a week I worked. It did not take me long to recognise that exact corrective feedback to continuous writing was the secret to effective teaching and learning - not a pedagogy I found that most university academics feel obliged to follow.

When I left my inner-city family after three years at Central Tech and Parkdale Collegiate, my choice was not supported. The students and the school principal were upset. I remember his warning me, "you are a teacher, and the university does not really care about teaching". But a new stage of the unplanned vocation was taking over. The rule-bound administration of the schools fostered an anti-intellectual milieu - more so than the illiterate kids and teen culture itself. The maximum security institution is not a good model of education. The language of "detention" for the extension of the school day tellingly revealed the model.

The worst thing about the educational world outside the university was that there was no academic freedom to enable the life of the mind to open and flourish. The environment of a university seminar and the openness to any critical issue or questions was a taboo in the schools. Ever since those days, I've thought that if there is any single positive reform for schools across the world, it is the right and duty of academic freedom in all public educational places. The academy leads in forming the next stage of human evolution by this principle, but it keeps it to itself - the right and responsibility of informed reason to know and speak, the unwon civil right of any developed society's workplace or school.

In place of this principle, another model has prevailed with no accountability. "Educational standards" themselves have come to mean corporate-style mechanisms of "quality control"over uniform school outputs, with education being reduced to passing performance tests. Prescribed behind closed doors, the "benchmarks" are not open to the scrutiny of teachers or anyone else before or after all are compelled to be subordinated to them as authoritative and final. I have been an invited speaker to the Deans of Faculty of Education of Ontario on this topic, and no-one could provide any source for the content of the tests or how to examine them. From what I know, the questions and choice menus of right and wrong answers are formulaically blind to critical alternatives and ambiguities of assumption, with open no trial of them. The agenda of top-down command and prescription of truth is familiar. It is the corporate model of education. As Ross Perot, who made his money from the business of educational testing, demanded on $\mathrm{CNN}$ the eve of the 2000 US election, "program 
them like computers". It is no accident that "academic testing" has become a blanket order in our era, and a big business in itself.

This is how a society dumbs down systematically. Although the university is the source and model of academic freedom, its opening force of learning is not disseminated beyond its walls. The academy's truly core service to society has not yet been undertaken although the "freedom to question and criticize without deference to established opinion and doctrine" is the heart-mind of being human.

The World Compelling Re-Search of It:

The Emergence of Vocation in the Academy

After I had been away from grad school university for five years, I was the beneficiary of a remarkable blessing. I was awarded a PhD fellowship to study Karl Marx's work at University College, University of London with the now Chichele Professor of Social and Political Theory at All Souls Oxford, G.A. Cohen. My interest then in Marx's thought was rooted in the life-world the academy avoided. But Marx's work - with which I had no real affinity when I started - gave me both a real-world ground of discourse and wide horizons of possibility at the same time. What I was going through was what the scholastic aphorism almost states in the formula, determinatio est negatio. I had to reject what the academy was not to find what it could be. The process covered a lot of life first.

My condition was a familiar one to our kind. I knew I had to move towards a rethinking life, but did not know how. While I was teaching school, I was also writing a column called Dissent for the Toronto Telegram along with a roster of more eminent persons. I was also writing and interviewing for A CBC public affairs program called Through the Eyes of Tomorrow - as well as helping lead what the media called a "young turk movement" to turn the OSSTF toward more vigorous representation of teachers and public education. It was a fireworks time of engagement and public expression on top of school teaching, and every dimension of it panned out in unpredictable directions.

What I increasingly longed for was a vocation where thinking and writing through were not limited by bureaucratic frame, media entertainment for consumers, proprietary concerns, political shmoozing, or contexts of vast ignorance. I pined for the open time and reading to figure out the ever-deepening questions which were emerging. If only I could get to the bottom of the world mess I perceived and find a way out, the long massacre of human souls might be somehow relieved. A way beyond the life-blind round was my yearning of the soul. I felt an invisible prison that needed to be broken out of, but did not understand what it was.

Before I applied for a PhD fellowship, I took a year of leave from my teaching job with the savings of my work and traveled with my new wife, a daughter of the man who had been the CEO of the Avro Arrow project. That world journey overland turned us both into revolutionaries without understanding the cause. We drove and slept in a Volkswagen beetle from London through Spain and North Africa up through the Italian boot through Eastern Europe and the Middle East to Afghanistan, Pakistan and India and back again to London by another route without covering the same miles twice. What I had experienced in the inner-city schools of Toronto in the way of 
injust deprivation of human lives was multiplied by what I saw living across the world on less than a dollar a day with no more than village wells to draw water from and no place to rest but the fall-back seats of our small vehicle. I lost 70 pounds over the year and everywhere beheld the same pattern - immiseration of the majority, autocratic privilege of the elite, and group-minds across borders who never thought beyond their own lot. When I returned, I saw the same inlooking-looking bubble, but much amplified with cars and conveniences.

Only the Kurd grad students who hosted us in Iraq and the cold war propaganda on both sides I read as we moved across continents posed the questions of a socialstructural disorder - a structural disorder never conceived in any university course I had ever taken at the undergraduate or postgraduate level. The great ecogenocide was becoming ever more evident to my experience, but was nowhere discussed. The name of Marx and the doctrine of Marxism was pervasive pro and con in the mid-sixties when we traveled, but I pooh-poohed his theory as I had learned to do from my academic studies. But when it came time to choose an area of research that would not wind me into academic detail functions unrelated to the life-and-death problems of the world, Marx's primary sources were what I chose to study to keep a lifeline from the ivory tower to the tormented world I had seen.

My initial thesis idea after reading Capital through page-by-page was the inner logic of Marx's imagery as the untapped meaning and appeal of his classic work - still an unpublished project. I was quickly converted into thinking in terms of regulating principles without images by my PhD studies in a British analytic philosophy department whose method presupposed "poetry" as alien to philosophy. This metashift of understanding reflected my switch from English Literature, my undergraduate major and first book as a teacher, to Philosophy as a full-time graduate student. How do these domains of the academy relate? Literature is how it means, by images, rhythms and stories. What it means in concept and argument is philosophy. The one is truth in trope, and the other truth in principle. I thought Literature and Philosophy were married, but they were separated in the academyalthough almost no-one talked about such things.

So what was one to do in the academy where they are not connected? I chose to keep the expressive image and sound married to rigorous logical structure, and added in empirical social science to make both honest. But my holistic comprehension and practice were essentially alien to the given scholarly discourses, and so I let them unite hidden beneath divisions in the deed of my writing. I was just glad to be allowed to be free to try it, and still enter a philosophy program where poetry-free analysis of concepts was the ruling method. Again, the academy had left doors open to allow a new form.

I suspect I was selected by the Canada Council for a PhD fellowship in London after years away from university research because both committees looked beyond the normal credentials of the permanent schoolboy. Yet from what I have seen since, I do not think my chances would be good now. The academy selects for academic careerists who have done little or nothing else. I have been forced to the regrettable conclusion after many years that the "academic career" is an idolatry of the profession for professors and grad students alike, and screens out any thinking position which does not serve its demands alone. So unexamined is this prejudice 
within the academy that the vocation and the idol have silently and incredibly come to mean the same thing.

The unanticipated consequence of the equation of academic career-climbing to advanced research is that paradigm-challenging research is discriminated against to advance careers at both individual and institutional levels. The careerist does not dare to take risks, and the departmental community abhors what threatens its turf. The result is pervasive normalization of the research spirit. Once the ruling interest of the academy is assumed to be self-advancement within dominant paradigms, the limits of thought are set. I learned this name of the game over years, but was sustained by the more ultimate purpose of the academy and being human. More inclusively coherent consciousness had no walls of division.

On the overview plane of reflection, it seems rather undeniable that the real evolution of humanity occurs by its members' thinking past accepted ways of understanding the only way we get beyond what is wrongly assumed, in the academy or anywhere else. In the academy's vocation of explicit consciousness open to test, it leads the world. So the reduction to a given technique driven by self payoffs within set bounds has long struck me as a betrayal of the academy's trust and mission. The idolatry of the "career path" and "departmental reputation" have long led the way in this reduction. When such ends become ends-in-self, they reverse humanty's cognitive evolution.

As one who was allowed to be free of this regime most of the way, my observation from 40 years of experience is that only those choices that select towards climbing the academic ladder are conceived as legitimate and rational- in graduate school awards, tenure-track jobs, promotions, committee-awarded money increments, and departmental rankings in the discipline. Anything else "does not count". One could, for example, write articles for the public whose taxes support us, and these articles could even be eventually republished as chapters in university textbooks - but they are disregarded unless they appear in academic journals of the particular department's division of mental labour. There are many examples of this blindspot of departmentalism including my own career experience.

This is why ever more reworkings of stock arguments and issues of a disciplinary specialty can gain career points without limit, while original method or exposure of unexamined principles are ignored. This seems also why self-referential specialist discourses multiply within the academy. Everyone and every department must have "recognized areas of specialization", and containment by them is usually the price of survival. "Publications and research" can in this way come to be an operantconditioning box regulating the mind to conform to the currently ruling repertoires of value and meaning. It was made clear from the start that it was dangerous or incomprehensible to question this regime.

So a formula of performance keeps careerists in bounds. They stick to already longdiscovered ideas and findings, their stock problems and limits of discussion, and do not connect across them. At the same time, it is taboo for anyone to expose the regulating value-sets producing this internal regime or the growing problems of the real world. At bottom, one inhibiting operator rules. Whatever does not select for higher status or revenues on the individual, departmental or institutional level is screened out in advance - except for the exceptions that keep the whole enterprise 
afloat. The logic of the academic game works against the academic vocation, and few make it across the abyss.

Decoding the Academic Game to Find its Vocation

I went the opposite way because I never had a career to begin with. I came in fresh from the wider world and did my best at what the university is constitutionally mandated to do - to advance learning and disseminate knowledge and serve the betterment of society. As soon as I discovered these constitutional objectives to which the university was accountable, I understood what the academic vocation was in law and was guided by its touchstone and anchor. Yet I only found out what it was by reading the University Acts which were not then produced in any calendar or spelled out in any university, college or department publication. It seemed as if a great victory for higher education and the wider community had already been won and written into statute, but made somehow silent within the university community itself. It was moral DNA. Yet serving the objectives was perceived on the $t$-and-p game level as a fool's errand or troublemaking, and I was never sure I would last to "progress through the ranks" - a standard phrase that reveals the military mechanism at work. The reason for working hard at teaching, research and service in a higher education institution did not seem to be to live up to the obligation of this great privilege of vocation, but rather, to win/lose higher rank and money privilege for oneself as the career objective of any normal person. I gradually recognized this as the same atomic, self-maximizing metaphysic as the capitalist market, but I could never get over its internalization by the academy itself. Not even Marxists, so far as I could see, challenged it.

What kept me in through even the "academic mobbing" that Ken Westhues has since brilliantly exposed was the inherited constitutional values of the university. I believed in them as a trust conferred by human evolution itself of which I was a beneficiary and expected contributor. I think that beneath the divide-and-rule game everyone thought they had to play, most respected the academy's higher vocation. They were not consciously driven in their work by the self payoff mechanism of rewards and punishments so much as regulated by a preconscious syntax of academic meaning - a very dangerous regime when left unquestioned. The academic mobbing of dissidents or non-conformers to the ruling order - which could be anything from a dominant methodology to administrator run-games to anti-communist acculturation - was the downstream result of the group-mind regime. Overall, I found the higher values of the vocation won out, but only if one fought to the death for them independent of one's own interests.

Beneath the career-versus-vocation conflictedness was a deeper bedrock. I have never stopped being grateful to our forbears and the public who enable universities to exist with this vocation. For this reason, the "publish or perish" rule always seemed to me a fair requirement. A faculty member was provided with a decent livelihood and time to think problems through to a lasting form that can sand up to criticism through experts and time. That was the agreement of the vocation. The real problem with "publish or perish" was not the imperative itself, but the incompleteness of its requirement. When it is reduced to publishing in specialist journals inaccessible to most people, read by almost no-one, and usually in conformity to current topic fads, it becomes a kind of charade. 
Nonetheless, it seemed that every discipline and department went through this ritual reduction of "scholarship and publication" in some form. At the end of each judgement period, institutional administrative committees count the entries and names, reward or deprive according to added numbers, and no-one reads or engages the arguments in debate. Too often academic advance seemed to come down to being favoured by a well-positioned few in the dominant group, with a feudal hierarchy of names faithfully limned across faculty and grad ranks in each discipline as the context of ruling meaning. Symbolic orders go begging for questions that cannot be posed because they don't fit the disciplinary mind-sets in vogue. Or at least that was the undertow of the academy I experienced.

For academics break out to wider horizons of life meaning. The risk:success ratio is high and few dare to go it alone. Yet the University is constituted by its core obligations to enable faculty to do just this. In my experience, the public university generally lives up to this constitutional obligation to the extent of not directly interfering with one's teaching and research. Few faculty may in fact argue for any new regulating principle of critique and explanation, but this is because the "career path of progress through the ranks" is what they have been conditioned to commit to as their positional good. As I look back over it, I recognise how many exceptions to the self-serving game there were. There were always people in the university, often out of nowhere, who felt the calling of the life of the vocation very deeply without whom I, for one, could never have survived. I think there may be a deeper covenant at work here which is as old as the academy itself.

\section{The Life-Ground Test of Inquiry}

Before I entered PhD studies, I had experienced a lifetime already - a sports career, three years in inner city schools, work as a free-lance print and television journalist, and a year of overland travel to India and back. I had been turned inside out, and was hungry for thinking it all through. My mind was like an open wound, stitching and stretching and stitching to bridge all the differences and distances of meaning I lived with.

On the ground, the re-entry into the university posed more immediate problems. My wife and I had to sleep with our baby in a van for the first six weeks of my re-entry into the university at one-third of my former income. No-one would rent a flat to a couple with an infant, we bathed in institutional washrooms, and the University of London had not yet decided I should be in a PhD program, "a North American degree", until they saw on-site academic work. That my fellowship depended on being so registered as we lived out of a parked van was the background to the paper I wrote to decide my fate in the first 40 days of my re-entry.

I got through the shock treatment with the assistance of the academy's deep culture. Long dives of the mind into new levels and zones of thought was pure delight, but there was a greater emphasis on rigour of reasoning through. My PhD adviser later confessed of his teaching method, "I knock them down, and if they get up I knock them down again, and if they get up again, I do it again, and if they keep getting up, then I know they will be fine". I don't agree. My grad students have always seemed to me to need as much supportive help as I could give them in the complex geography of the mind we travel. But for me, continuous bouts with a razor-sharp mind did 
wonders. Some people have told me they think my ability to write for a popular audience was ruined by this philosophical training. But it taught me to walk very carefully through the minefields of ignoring the unseen - the ignorance that lies behind most of the vicious stupidities of the human condition.

In my re-entry into the academy, I especially recall an upsurge within me that was to define the nature of my academic projects. My epiphany was set off by a scholastic debate about whether the "average 2.5 children family exists" and whether "being black" affects the fact - the latter question raised by the sole black student in the seminar. A new generic question began to form in my mind to bring academic argument to ground. I don't think I have written or attended a paper in over 45 years that this question has not recurred as my wider field of meaning:"What is at stake that this position overlooks? What life capacity of our world does this argument help to release or to repress?" I call this the life-ground test. It has taken me on endless journeys into the meta-program of the human condition and its presupposed orders which I still pursue day in and out.

But let me be frank. There are endless barriers to such a way of thinking in the actual academy. I experienced them at every step. At the most unexamined level, there is a silent methodological censorship that is structured to avoid questions that disturb the ruling assumptions of the disciplinary guild or the wider society in which it is embedded. I could go on about centuries of philosophers' silence on human slavery, the accepted oppression of women and children as chattel, private money sequencing overriding countless people's lives, gagging of whatever does not conform to the syntax of ruling privilege, blind self-seeking and disabling violence within system roles as moral duty, and most generally, regulating group-mind formations of every kind that destroy the conditions of flourishing life.

Academic cultures, I was surprised to find, are also submerged in these day-to-day regimes of oppression. Indeed, as Marx pointed out, they "perfect the illusions" of the ruling orders - but not only ruling classes as he believed. Class membership does not explain the great differences among those in the academy who function as system apologists, those who are deep-structural critics, and those who sit on fences of denial. Diversion to problems whose study has no implications beyond itself may be the academic norm, but it is not explicable by money-capitalist determination. A lifeblind logic of value seems built into the university's disciplinary structures as we practice them.

That none of us have ever heard of any tenure and promotion committee considering the life substance of a publication as a standard of its worth points towards the problem. One might more favorably research $\mathrm{x}$ on y on z's interpretation of m's position on one issue of problem $b$ - you can fill in the logical spaces across disciplines - as be discovering the grammar of academic blindness to the distinction between life advance and destruction. The axioms of modern economics, for example, are perfectly indifferent to the distinction between means of life and life-disabling commodities, while the more generic mechanics model of reality the sciences imitate are in principle life-blind. Such issues rarely arise in the academy, but there is no other place for them to be investigated as they rule the world.

A deep question is eventually unavoidable: is the academy lost within its multiplying divisions of labour? Does its assumption of the wider ruling order as given paralyze its capacities for discovery and understanding? A regulating disconnection from all 
such questions seems built into the methods of examination. It may be called "pure research", "objectivity", "irony", "distance" or "rigour" - there is no end of slogans to justify it - but the pattern is unmistakable across disciplines. At bottom, there are no identifiable bearings to favour life over death in the steering principles of any discipline.

Can we think of an exception? Even "the life sciences" regularly select for lifedespoiling engineering of life systems from laboratory to commodity in complete indifference to any problem. When I was on the Animal Care Committee of my own university whose departmental faculties sacrifice hundreds of thousand of animals a year, any criterion at all for distinguishing between life-serving research and research for private profit was taboo. Any protocol standard to rule out deadly tests on animals with no life-enabling function was repressed even by an oversight committee. On the other hand, the possibility of informed intelligence calling into question the status quo of life-blind ignorance is virtually everywhere to be pursued. But does it happen? The human and academic vocation alike demand it, but the path of more money or status from research rules as if they were the same thing. No more profound and instituted confusion afflicts the academy at individual and institutional levels. Unaccountability to any life value of research and knowledge beyond selfenriching results has in this way opened the academy to the private corporate takeover that has occurred.

\section{Taking Academic Freedom Seriously}

The life-ground test for pursuing an academic issue motivates actions beyond expectations of the acceptable. My own run-ins with unexamined academic structures have been continual and diverse, but reveal much about our condition. The run-ins have included, for example, near firing for refusing to grade students' papers until clear university standards of grade values were agreed to rather than numbers and letters with no deciding criteria.

Back when I raised the issue as a tenure-track but untenured faculty member, the Department Chair, Assistant Chair, the Dean, the V-P Academic, and "the department cabal" - the phrase of one of my graduate students - all voted to terminate my appointment. I was calling into question the currency of the university system, and no sin could be more heretical. Only a number of my fellow faculty stepped in and they eventually outnumbered the officials at all levels. This did not mean they agreed with me, but they stood for the "Socratic function", and defended intellectual rebellion against an order without reasoned justification. I realized then that the academy worked towards fulfilling its constitutional goals because some faculty stood for them.

Yet my experience has also been that the politics of the university tends towards normalization of the external powers-that-be. The perpetual offences against the life security and welfare of citizens by dominant state and corporate interests, for example, are typically rationalized away or screened out of view. When I and others publicly opposed the War Measures Act of 1970, which polls reported was supported by $95 \%$ of the population, I used the departmental mimeograph machine to print critical questions that were not raised in the media. Immediately, the common 
copying room was put under lock and key without departmental discussion. A colleague, an eminent philosopher of physics, advised me to lie low - not to silence me, but to give warning of dangerous times. I laughed because we were in a place of higher education, and this was an issue of defining importance. If we did not investigate and understand on behalf of the wellbeing and future of the citizens of Canada who specifically tax-funded the university's community "to inquire without deference to established opinion" and to "serve the wider society", who would? My colleague asked me if I was familiar with Dostoevsky's The Idiot. I thought I was fulfilling the faculty member's given obligation to advance and disseminate understanding to serve society - in particular when big lies were being propagated in an unsubstantiated "terror scare". (The terror-scare method became standard fare in the era to come.) As a philosopher, it seemed imperative to go the grounds of the claim and the life-threatening consequences it had led to. As a faculty member privileged by academic standards of freedom, the obligation was not one that could be avoided. Over 450 Canadians had been seized in the night and imprisoned without charge, while police expanded their vigilance in stopping cars with occupants who had long hair.

With local bigots calling for the round-up of more subversives and no substantiation of expanding scare stories carried by the media as facts, I believed my duty as a member of the academy was to examine the justification of out-of-control conclusions causing incalculable civil harm. As soon as I heard news of the War Measures Act and "the apprehended insurrection" which was required to legally warrant it, I took a train to Quebec to check out the claim. There was as yet no evidence of crimes prosecutable under the Criminal Code, but the suspension of habeus corpus and the rule of law across Canada had already been provided for by the sudden invocation of the Act. As it turned out, University of Guelph formed the first public or campus movement against the War Measures Act in Canada.

This was a paradigm case. But such occasions for expressing academic responsibility and freedom were continuous over the decades. Within three years, Canada was selling bomb components to the US during the "bomb them back to the stone age" period of the Vietnam War and a local business member of my university's board of governors was receiving incentives from the Defence Plan Sharing Agreement to manufacture military flares for a criminal war of aggression under international law and the Nuremburg Charter. I drew the university community's attention to the connections and the abetment by the board member of war crime with citations from international law. This became another national issue although the president of the university warned those who raised questions on the issue "to stay away from this one if I were you".

I will spare recounting the many occasions of life-and-death public polices requiring scrutiny that continuously emerged between 1970 and 1990. But I sought to respond to all that were being silenced. Perhaps needless to say, the numerous articles and arguments I wrote that were published by newspapers and magazines before the global corporate shutdown of public dissent silently took hold were not valued by departmental and college tenure-and-promotion committees. Their argument was that since no academic referees had formally judged them, they could not count as academic work. 
I accepted this as far as I could understand the academy's need to protect its own venues of publication from submersion by the corporate megaphones of the mass media. But that was not what any chair, dean or t-and-p committee ever suggested. In fact, every publication posed questions to this very regime and exposed regulating false assumptions across the town-gown divide, while not a sentence was submitted that was not exactly formulated to scholarly standards. No-one showed the contrary, but the work was "not refereed" in the only permitted sense of the term. Although there was an audience of hundreds of thousands of readers with many relevant experts continually provoked by arguments who would scour the text for any iota of error, only one form of "refereeing" counted. What did not pass the blinkers did not exist for committees.

I was actually relieved when the mainstream presses stopped publishing my contributions well over a decade ago. The embargo corresponded almost exactly with the triumph of evangelical global capitalism across borders. Nothing at all was now published in a corporate ad vehicle that called any of this "new world order" into question, and especially if it raised issues at the deciding level of ultimate values - for example, the value of more means of life for life against ever more pecuniary opportunities for private foreign investors. So I wrote academic papers and books on the deepening problem instead. They were published despite sometimes militant denunciations - for example, vociferous condemnations by referees when I wrote of the "system of fallacy" regulating the field of logic and the media alike. It only got published because I demonstrated to the editors that the referee reports instantiated the defining principles of the system of fallacy I exposed in every objection they made.

More recently, after the September 11, 2001 event and the official conspiracy theory for it, a Science for Peace paper I delivered at U of T became a media issue. My article (still on the web) was denounced by the Wall Street Journal (which called me "Osama McMurtry"), Fox TV News, and a flood of virulent letters to my university - one from a former colleague and celebrated Darwinian philosopher who had moved to teach in Florida. Yet I am glad to say that my Chair and the V-P Academic replied to the campaign with the appropriate response - that academic freedom protected faculty to write controversial positions not acceptable to dominant opinion. Earlier intimations that my work in the public realm should not carry any university affiliation were not repeated, perhaps because I was now over 60 and an elected fellow of the country's most prestigious academic society.

In the years shortly before my embargo by the corporate press and release into fuller time for writing book chapters and UNESCO volumes on Philosophy and World Problems, I got caught up in another battle to stand for the academy's vocation in an unpopular way. This conflict involved a $\$ 55$-million contract between Canadian International Development Agency and the Government of Indonesia (GOI) to have the University of Guelph "deliver services" to the GOI. The "Sulawesi Project", as it was called, operated from within the GOI's Office of Internal Security, and provided high rewards to faculty team members - handsome perquisites and per diem rates for consultant and administrative activities, many proceedings and titles for C.V.'s, and secrecy of operations at the financial and GOI levels. I asked the Project Director how we could be supporting infrastructural services for a "known genocidal government 
with hundreds of thousands to more than a million victims". He replied that the GOI was "one of the most progressive governments in the world".

Much of the next years were spent in sorting out that argument. The fireworks included a lawsuit against me by a colleague for libel by my public demonstration of his fallacious arguments, a continuing heated debate in the university's paper, and endless hours of argument in committee fashioning new "Policy on University Involvement in External Activities". Eventually after external and independent peer review (where the University properly goes on all unresolved issues), the matter was resolved. The contract was terminated. But it was the GOI that terminated the contract, not the University of Guelph. Senior administration refused to act in accordance with the negative report by independent referees showing violation of the university's academic standards and objectives that had all along been indignantly denied. Instead, the senior administration challenged the findings of the experts who had done an intensive study in situ. The pattern was an increasingly familiar one. University revenues trumped academic standards in proportion to the dollar amount of loss or gain involved.

One political scientist who named the game of academic self-serving that was going on was subsequently harassed for years by right-wing colleagues and died tragically and prematurely by heart attack. A colleague, whom as former chair of the department he had brought to Guelph as an internationally eminent radical political scientist, was then persecuted by the same means - academic abuse and innuendo without substantiation. The victim of the academic mobbing asked me to represent her, which I did over one year of monitoring the almost daily abuse of her by her chair and dean. It was all another vast waste of everyone's research and teaching time led by academic bureaucrats with nothing apparently better to do. I have come to conclude that the university's internal organization would benefit by making all academic bureaucratic positions part-time rotating appointments paid by course offsets with no perquisites of office.

It was only when her appeal to a university-based appeals board with members external to the department and college was eventually won that the mobbing stopped. In representing her during that appeal, I was amazed how arbitrary the t-and-p committee ratings of zero she was awarded for her active teaching and research record over two years had been, and how completely they came undone under external questioning. The academic process had been distorted to effectively ruin her academic life - not for incompetence or lack of original performance (of which there was plenty), but because she did not fit. Once group-mind aggression against nonconforming values and expression starts, it behaves like lord of the flies. The only thing to stop it is an external reference body of expert opinion not anchored in the local group - the real basis of the refereeing process that is often violated in its name.

\section{The Totalitarian Threat}

Lurking behind the debasement of the academy by ruling group opinion is the wider identification of careerists with the ruling order - which in our era is the global regime of turning money into more money for private corporations and money syndicates. To get a sense of the academy's increasing submergence in the values of this regime, consider the words of Harvard President, Lawrence Summers, in an 
interview with the Globe and Mail on May 24, 2003. His presidency of "the world's leading university" tells the pattern in clear terms. He asserts "the essential truth" that all "basic value" - including, specifically, "literacy", - is "linked to market growth".

We may formalize the equation of the former President of Harvard as follows: More/less money-value sales $=$ more/less market growth $=$ more/less "basic values" for peoples. No substantiation of the given equations is necessary. No explanation of contra-indicative evidence is permitted. Mind-staggering implications follow that are not seen or considered by Summers or the Globe. Whatever is without a market price is without value - the world's biodiversity of species, for example. Life itself is of no value except as it sells for a market price. In contrast, anything becomes a value once its sells, such as cluster bombs and obesity foods. In these ways, the ruling thoughtsystem perpetually metamorphizes value into disvalue and disvalue into value, and who in the academy observes the pathological magic thinking? As the system globalizes and intensifies, its consequences are known as "new wealth created by the market" even as former life-value is annihilated with no new life-value created in its place, such as biodiverse forests turned into throwaway paper bags.

For the academy, the problem is fatal as well, but little understood. Higher education and university research have increasingly been reduced to a subordinate function of this "creation of new wealth", but simultaneously glorified as the leading edge of the so-called "knowledge economy". Who in the academy asks what "knowledge" means here"? I have not heard the question raised by university managers or policy makers, or even epistemologists, over 20 years. In fact, "knowledge" here means only those regulating ideas that most reduce money costs and increase money revenues for private transnational corporations in commodity production, distribution and consumption. At the same time, teaching comes to mean only what produces graduates to compete most cost effectively in the global market. When university people hear about the "need to restructure universities education to be more accountable", they seldom decode the real meaning of the message.

My experience is that few academics find this perversion of the university vocation deranged even as it turns academic life and conditions upside down. Rather, the reaction is to get funding from "corporate partnerships" brokered by governments, private foundations, and university research offices developing a new breed of academic entrepreneurs, while the university part-times teaching faculty. At the same time, higher education and research are defunded in their constitutional purposes advancing human learning and disseminating knowledge as an end-in-itself. We have all watched the symptoms of the derangment grow. University education is conflated with training students to serve the labour market, and ever higher tuition fees are conceived as "investment costs for having higher priced market skills". Selling students and campus grounds as marketing sites is so prevalent that any other alternative seems inconceivable to the university's managers. A commercial creep advances through the campus with no evident limit - corporate ads, junk foods and market franchises invading space and sightlines across buildings, and brand names posted on lecture halls, research buildings and even courses.

Perhaps the deepest level of violation of the higher learning vocation has been at the level of scientific research itself. The redirection of public funds to private for-profit uses has invaded every domain - in particular, the use of university faculty and 
resources for the development of corporate commodities and ever new priced inputs pumped into people, animals and ecosystems whose consequences are not tested. At my own university, most of the agricultural and veterinarian research is channeled into such products (eg., bovine growth hormones and GMO's). In general, the mission is to "bring university research to market", increasingly leveraging the academy into service to large private-profit enterprise in every domain from pension funds to ads in the toilet.

What was once unthinkable in the free academy - research and resources for private monied interests - has come to be equated with the academic and public interest. Where is the distinction made between them? The absurd becomes normal as administrators and careerists on faculty are made parasitic on the process. How did all this happen without any debate? It started in a simple way. Beneath any official notice, government funding apparatuses from the late 1980's on simply reversed their terms of funding research - from non-profit requirement to for-profit partnership. I remember at the turn towards this silent sea-shift publicly asking the chair of my university's board of governors, Edmund Bovey, to distinguish between the corporate and university models of education as he advocated "business management methods" - and his glower of non-answer. But I had not yet clearly recognized the depth of the takeover being strategically planned. In general, the strategy of subjugation was straightforward - reduce the financial bases of universities to coerce their compliance with the private for-profit regime of the corporations. While this regime was throughout falsely represented as "the economy", a conception echoed by even the academic critics of the university's subjugation, the public economy of which the universities are the heart and mind was hollowed out at its core.

The dumb-down of the university system was not confronted by "academic leaders" at any stage of the process. Instead, university presidents conspired with corporate executives "to continue the underfunding policy - thus creating greater incentive in the university community to seek out corporate partners" (as Howard Buchbinder and Janice Newson explain in their 1991 article, "Social Knowledge and Market Knowledge, in the Gannet Centre Journal, 17-29). This direction was planned in a report of the Corporate Higher Education Forum (CHEF), founded in 1983 to join 25 university presidents to 25 senior executives of major corporations in setting the "new direction" for universities which were increasingly in crisis from government defunding. The acronym itself is a sign of the parlous conceit at work. The universitycorporation partnership was, however, less than equal. The universities were losing funds from government, while private corporations and stockholders were gaining them by massive tax-cuts and new subsidies. At the same time, corporations set the agenda for universities at every level, while universities had no say whatever in the direction of corporations whose sole obligation under law is to increase private profits. The outcome has been that university presidents increasingly jump like lapdogs to compete for corporate funding, while corporations became ever more empowered to set all the terms of university revenue streams. A silent privatization of the universities was thereby accomplished with the presidents and central administrations of universities acting like junior executives in the occupation.

It was not easy to find any colleagues who realized what was going on, then or since. CAUT and selected scholars knew that the university funding crisis was an integral 
part of a social-structural shift to total marketization that started with the ReaganThatcher revolution, but the lines were not clear. All followed one crystal pattern stripping the funding of the academy and the public economy at the same time, while marginalizing the academy's role as an independent critic. The funding slashes thus accompanied lavish tax-cuts and subsidies to corporations and the wealthy. The downstream consequences were faculty and course reductions in the non-marketable disciplines, and ever higher student debts.

The connections have not registered yet in the academy so far as one can see. Rather, central administrators have led the cutbacks with caps in hand, while departmental researchers have been structured and paid to serve the causal mechanisms of the public dumbdown and stripping of the university.

On the wider planes of society itself, the restructuring pattern is expressed by continuous privatizations of public services by direct sale, private-sector management of resources, contracting out and part-time staffing, cutbacks of public and environmental health, education and other social regulations and services, and - in general - eliminations of all social expenditures which do not serve the corporate market system.

Increasing pollution of our air and water since the privatization and private-public partnerships began are the "externalities" of this overall process of for-profit marketization of society.

Debasing changes in the academy such as external funding requirements for almost any higher research project at the graduate or faculty level simultaneously extend the pattern into the academy's bone marrow. Subordination to money-sequencing drivers and limits is made internal to the research process itself in the humanities and social sciences as well as the natural sciences. Nothing could more effectively censor out system-critical research and understanding in the long term.

Countless university administrators have assured me that they act only so that funds are found for our common mission. The conflicts of interest in steering objectives and methods are simply blinkered out. In the standard "university-corporation partnerships", as we know, university researchers must find projects which big business is willing to co-fund. This means that what corporations find no profit in for example, preventative medicines for third-world malaria which kills over a million people a year, or diet-exercise routines to prevent epidemic diseases in our own society - are not funded a penny. Within government, the conflict of interest is instituted. Private corporations fund or self-research the safety of their own new products, and scientists who reveal hazards - like University of Toronto's Nancy Olivieri - may be fired from research positions for identifying them.

Any independently thinking mind in the academy can recognise the remedy. On publicly funded campuses, rule out private-profit research that serves special interests. Research that is directed to exclusively commercial or doctrinal interests fundamentally violates the university's objectives. Let the corporate donations come to the university's autonomous mission of knowledge advance, but not to fund the donors' own research for private profit. Otherwise the research outcomes are biased by conflict of interest. One has to wonder, why has the most self-evident defence of the academy's research integrity been eliminated? Why have there been almost no administration objections, but only cheerfully servile collaboration? 
Have university administrators and faculty been so suborned by the violation of the academy's academic objectives that they cannot see what they are doing? In my experience, university presidents and v-p's are so committed to rationalization and denial that their siding with private market forces against the university's own vocation is invisible to them. As the eminent scientist and humanist, Ursula Franklin, has memorably said from her direct experience of the 1930's era of Germany in Europe and the academy today: "They had their collaborators, and we have ours". The sweeping collaboration of senior administrations against the most basic academic standards has had virtually no limit. One paradigm example comes again from my own campus. An official booklet on the research-market connection actively distributed by the V-P Research, The Canadian AgriFood Research Strategy 19972002 stated: "Increasing competition for research funding - - will demand that Canada identifies its research strengths and capabilities to focus on those areas with highest value and return on investment - - Priorities for applied research are set by the marketplace via partnerships eg. industry funds research that fits their priorities. - - Augmented private sector participation in research priority setting will - - ensure scientists have access to the appropriate market signals, are aware of the technology requirements of industry, and can focus their research appropriately".

Note how the university researcher is reduced to a reaction formation to market price-signals (ie., how much fast money there is in the research?). Observe that the federal government implicitly commands the conformity of university researchers to this market-servant role (ie., no public funds unless you comply). Most blatantly, the office of the V-P Research actively propagates this imperative to faculty to abdicate their research independence and the university's academic objectives in applying for funds. No senior faculty in the areas affected stood against the reversal of the academy's vocation and the university's faculty association remained silent throughout. This is how the normalization of an occupation occurs.

As far as I could work out from inquiries, faculty were motivated by their need for research funding and fear of losing what they had if they spoke out. In the words of a lone colleague who broke the silence and receives virtually no funds for her own leading agricultural research: "Non-proprietary research of the sort that benefits everyone is of no interest to industry sponsors". As a result, independent research in the public interest that is most urgently required is silently selected out - for example, integrated pest management, organic farming for productive efficiency, managementintensive grazing, small-scale producer co-operatives, and alternatives to factoryprocessed livestock and to ecological contamination by genetically-engineered commodities. In fact, all of these domains of constructive research for sustainable agriculture and the public interest have been effectively defunded and attacked as non-conforming - even as the public need for these researched alternatives becomes a matter of life-and-death significance for farmers and the world. Such degradation by marketization of research remains blinkered out by university administrations, while individual faculty who do not conform are almost hounded out of the university. The academy thus abets within its own walls the totalitarian threat to society with a generally complicit faculty.

\section{Beyond Market Self-Serving:}




\section{Recovering the Academy's Vocation}

My experience of the university extends over almost half a century. For the first 20odd years, I was worried the place was disconnected from the real world in selfreferential guild specialties. For the next 20-odd years, I have observed the cumulative subordination of the university to corporate-market methods and privateprofit projects. Both trends betray the academy's constitutional vocation at collective and individual levels.

How has this happened? On the one hand, corporatization of the academy has undermined it from without by funding levers described above. On the other hand, most academics are so caught up in their own careerist micro-worlds that they are profoundly ignorant of the academy's meaning as an institution of higher learning. They have come to violate its most basic principles as an everyday necessity of their private self-advancement - the formula for academic corruption.

When I retired from the university classroom and on-campus faculty in 2004, I felt that for the first time I was free to pursue the vocation of higher learning and research publication without such corruption. With my files of current research for contracted publications growing beyond the dining room table I'd already occupied, I started to clean up my filing sites. The first files I came across were records of annotated university rules, issues and deciphered mazes of ever changing regulations, correspondences, institutional directives, and endless administrative review processes - countless stacked files and volumes of them including academic confrontations over decades that had already flooded into my basement to occupy more storage space. It was a bit like an end-of-life dream - all the petty angling in the bureaucratic foreground obstructing the university's higher calling.

I felt blessed to be free at last to fulfil the constitutional objectives of the University without diversion - to advance learning and disseminate knowledge for the betterment of society as my final purpose without obstruction by the corporate academy.

One great confusion has undermined the university's work for the last 20 years. The objectives of the academy have been submerged in a global market worship that cumulatively overruns planetary life-organisation itself. "Leave it to the market", "let the market decide", "do not interfere with the market", "bring your knowledge to market" - an idolatrous group-mind has come to rule within the academy too. In the words of one professor, deputy minister of education, and head of a major national research granting council over a decade ago: "I contend that the one global object of education must be for the people of Ontario to develop new services which we can offer in trade in the world market" (quoted by William Graham, "From the President", Ontario Confederation of University Faculty Associations Bulletin (1989) 6:15). This position is incoherent in principle, but increasingly reigns across the educational system with no notice of its absurdity.

While many faculty slumber in the metaphor of "a market of ideas", they do not penetrate the underlying contradiction between the market's exchanges of private assets for a price and the university's basis in a free community of ideas. Academics have become too busy being "specialists" to connect across the divisions of their 
mental labour to the university's shared vocation. I asked a chemical physicist recently why physicists did not challenge the nineteenth-century model of engineering mechanics assumed by the neoclassical economic paradigm, and he said "the physicists are too arrogant to talk with them". I asked an economist how she could imagine that this lifeless mechanics model could possibly be adequate to human society's development, and she looked at me as if I were from the moon. "Only economists can understand economics", she responded.

Meanwhile students know that going to university is necessary to "get ahead". So they do what they must to get ahead in the market. I used to ask my large first-year classes in philosophy, "What is the goal of a university education?" There would be a long silence, and then a further question: "those who think the primary goal of a university education is to make more money, please raise your hand". About 95\% would raise their hands - more and more after Ronald Reagan became popular as the US president with a credo of "American freedom is the freedom to get rich". University presidents, campuses and academic units have followed the market agenda. The presidents are reduced to cap-in-hand fund raisers in the CEO sector, the campuses have become pervasively festooned with corporate ads and brands, student market surveys have long decided the ratings of teaching performance, common academic spaces morph into sites for commodity sales, and multinational corporations control the textbook and journal production system in accordance with profit-first values. Who notices? In the climate of opinion in which we live, the response is likely to be "it is time anyway that the university was connected to the real world".

While it is difficult not to agree that the university should be linked to the world it is embedded in, corporate marketization moves in the opposite direction of the academy's objectives. First of all, the academy's purpose of critical search for truth is a goal that opposes the corporate market's final goal of financial self-maximization. For example, it makes no sense in the global market to oppose slavery or 80-hour work weeks as long as they reduce costs for investors and consumers by these forms of labour purchase. On the other hand, good reasoning and research require educators and researchers to consider life-destructive practices independently of their money payoff to private investors, and even in opposition to them. They may even know that it is irrational in market terms to devote long hours to research and rewriting if it simply adds costs to the producer and does not sell, but this is what original research demands in the academy.

Unfortunately, senior academic administrations are now unlikely to defend the advance of knowledge when it is not profitable to do so, but actually assist wealthy corporate interests in the silencing of academics who do so if they compromise these private interests who direct increased funds to university administrations. Here is an example of a true claim which my university refused to print in a paper I presented to address this problem. (I was referring specifically to the case of Dr. Nancy Olivieri explained above). I wrote:

In the case of University of Toronto, Dr. Olivieri's censure occurred while the President, Robert Pritchard, was in the midst of negotiations to receive a multimillion dollar donation from the corporation trying to silence Dr. Olivieri. 
Administrators who presided over false attacks were promoted to more lucrative positions - including the current President of University of Toronto. On the wider government plane, the incoming federal administration of 2004 campaigned on the "tripling of the commercialization of university research", which Paul Martin proclaimed as he became Prime Minister was "not nearly fast enough.

My observation was not contested because I presented documentation on every point. But the university administration would not print these sentences in the campus bulletin reprinting my address. The reason given was that external commercial legal counsel advised that it not be printed even if the statements were perfectly true (and truth is an absolute defence against libel). Here we may see how the values of the corporate market and the academy conflict all the way to publication of reports of the conflict itself.

A second level of contradiction between market and academic models is between the methods of dissemination. The control of all knowledge that corporations can copyright or patent is an ultimately regulating principle of the global market. Indeed, this right to market monopoly of ideas is pursued and extended to the utmost by 20year patents on life-saving remedies, control of seed varieties, and corporate copyrights on journal articles and texts - all typically discovered within universities themselves. I have even been stopped by my own university library from putting relevant article and chapter publications on reserve for students when I am the author of them.

This is the extent to which the university has gone in not only accepting the corporate agenda of education as its own, but in enforcing this agenda on the academy's faculty and students against their learning interests. It is now a general fact that academic journals themselves have become copyright-controlled by private corporations' buying up the journals, and then multiplying the prices for their purchase and use by university libraries whose own faculties have created the material for no cost to the corporations. Indeed there is a standard copyright form required to be signed by faculty authors whose work is produced and refereed free for corporately owned journals, and these forms demand exclusive world copyright in perpetuity to the private corporate proprietor for no returns to the author, the university or the public who support both. I always add a specific condition removing this exclusive world copyright, but typically risk or am threatened with non-publication. There has been no such resistance to signing these forms, I am told, by other academic authors. Thus the public, the students and the universities pay for faculties to research and publish and for all the university resources to support them, while private corporations buy the vehicles of publication to sell them back to the university communities who have created them. This market game generates private profits to the corporations which have paid no costs of creation for the products sold, and charges university libraries increasingly unaffordable prices for journals and texts. The extent to which the academy's freedom of knowledge dissemination has been usurped is a measure of its collaboration with the invasion of its learning foundations. Yet few notice the undertow pattern - least of all university administrators and government funders who increasingly press for more commercialization of university knowledge creation. When such hijacking of publicly- 
funded academic resources for external private profit goes unprotested and unflagged, one wonders as to the intellectual competence that remains in the academy's ranks.

On the level of practice, fleecing universities of their own creations by exclusive corporate copyright extracted from university authors as a condition of refereed publication is systematic extortion by external agents paying none of the costs. On the level of academic integrity, the university's method of free and open dissemination of ideas is the very opposite in principle to exclusionary copyright for private profit that blocks the free exchange of ideas.

The betrayal of the academy's vocation seems to have reached into our very identity as persons and academics. Development of abilities of autonomous thought and action is what the academy promises and is tax supported to provide. In direct opposition, consumption of ready-made commodities is what the corporate market provides to those alone who can pay for them. We know that if anyone tries to buy their way into or through university, s/he is liable to expulsion as a cheat. But if the academy follows market values, why shouldn't students buy their papers from sellers of their choice? If all that is involved is an exchange to get what you want for the least price, the free market way, why is buying academic papers wrong? The rising epidemic of internet plagarism is not anomalous, but symptomatic of the increasing dominance of market values in the academy.

The ultimate assault on the university's vocation is at the level of truth-seeking itself. The university is constitutionally committed to critically reasoned inquiry which goes wherever the quest for truth leads it. The truth is not an end state, but an open process in which partialities are continually exposed by thinking through assumptions, evidence and connections. This thinking through is the nature of learning and knowledge. Reason's movement is always by a more inclusive taking into coherent account that is open to shared counter-evidence and argument. This inner logic governs all disciplines - from the problem of self and other in philosophy, to the nature of tropes in literature, to the hypotheses of subatomic waves and particles in physics. In one way or another, the critical search for more comprehensively conscious understanding leads the academy in every domain and the human condition itself.

In direct contradiction, market enterprises and corporations succeed by one-sided conditioning of unconscious desires of buyers so as to maximize sales of products for private monetary returns. The truth is what sells. If sales increase by imaging and commercials that stimulate primeval appetites of lust and violence, then these are deemed right so far as they promote profits and sales. "We are only giving the people what they want" and "no-one is forcing anyone to do anything" are the rationalizations. How does one confront such a reversal of cultural evolution? One can only go to the more basic value of conscious understanding that enables human life to be human. This is the vocation the academy exists to forward, but its mission has been sold out to a life-blind regime that depredates as it invades.

\section{Conclusion}

After over 40 years in the university, I see it morphing into a garage sale of the mind. While I directly experience the university's vocational core in my life, research and 


\section{Nordicum-Mediterraneum}

publication with all the academic resources I require, I increasingly find this vocation blocked within the institution itself so that it has become marginalised. My own university is a paradigm case. It is repeatedly chosen as the best comprehensive university in Canada, and has internationally leading research complexes devoted to, in particular, the sciences of food production and consumption - biological, economic, veterinarian, and agricultural. But there is no criterion of organically nourishing foods or products stated or implied in any one of its schools, programs, or mandatory courses. This condition becomes more debased as it totalizes.

As with every other university in Canada I know of, for-profit food services for students specialize in junk foods, rich leases are granted to monopoly providers, and competing commercial propaganda sites increasingly pervade the academy's field of meaning. Virtually all of the university's administrative coordinates select for moneyreturn value over enabling conditions for learning. Corporate-ad vehicles and pecuniary alliances are the dominant frame of reference at the management level, and programs follow suit - for example, by administration rebranding of courses into interdisciplinary clusters with no new faculty capacities but more administrator offices and perquisites. Since central administrations adopt market and corporate management techniques as their model and hold the academy's purse strings as their exclusive preserve, they are governed by no academic code of allocation and are rarely held accountable to any academic authority. To distinguish knowledge from self-enriching falsehood is not possible within a totalized corporate culture, and its conditions are already largely established.

Are universities now deprived of their bearings of truth and moral compass? Not at all. Their instituted objectives of "advancing learning and disseminating knowledge" and "the betterment of society" remain the academy's given common ground and direction. They are the vocation of the university and of human civilization itself. But living up to them is what has been lacking. 